\title{
The Relationship between Land Ownership and Range Condition in Rich County, Utah
}

\author{
MICHAEL W. LORING AND JOHN P. WORKMAN
}

Abstract

A study was conducted in Rich County, Utah, to determine the relationship between land ownership and range condition. Analysis of variance and paired-plot $t$-tests were used to compare range condition ratings on Forest Service, Bureau of Land Management (BLM), state, and private lands. Forest Service land was in the highest range condition, BLM and private land had comparable intermediate condition ratings, and state-owned rangeland was in the lowest condition. Per acre graxing program expenditures in Utah by various land management agencies show an apparent correlation between expenditures and range condition. Thus, range condition may reflect management effort rather than the structure of public land property rights.

Key Words: range condition, land ownership, property rights structure, privatization

The relationship between land ownership (and associated property rights) and the use and health of renewable resources was an important focus in recent arguments to transfer federal land to private or state control. While the economic consequences of some such transfers have been addressed (Workman et al. 1981), there is little information concerning the impacts of ownership transfers on range conditions, long-term forage production, and erosion. Advocates of privatization suggest that the lack of efficient and well-defined property rights governing public land use has led to ecological degradation. They maintain that private ownership of natural resources is the only way to avoid resource depletion (Baden and Stroup 1977, Hardin 1977). Opponents of privatization contend that the market fails to address the public good of long-term ecological stability. They provide many historical examples to illustrate the short-sighted approach of the private sector and resulting mismanagement of western rangeland (Rosetta 1985). Neither side, however, has offered comparable quantitative data to support their positions.

Some published information is currently available on the general condition of grazing land under the management of the Bureau of Land Management (BLM), Forest Service, and the private sector. Table 1 provides the percentages of grazing land in

Table 1. Percentages of total Utah rangeland acreage in each range condition class for each ownership.

\begin{tabular}{|c|c|c|c|c|c|}
\hline \multirow[b]{2}{*}{ Ownership class } & \multicolumn{5}{|c|}{ Condition Class } \\
\hline & Excellent & Good & Fair & Poor & Other \\
\hline Non-Fed' & 2 & 20 & 47 & 29 & 2 \\
\hline $\mathrm{BLM}^{2}$ & 4 & 33 & 39 & 16 & - \\
\hline USFS $^{3}$ & & 27 & 46 & 27 & - \\
\hline USFS $^{4}$ & 13 & 36 & 37 & 14 & - \\
\hline
\end{tabular}

1 U.S. Dept. of Agriculture, 1984a (SCS condition classification is: $>75 \%$ climax vegetation $=$ excellent, $51-75 \%=$ good, $26-50 \%=$ fair, and $\leq 25 \%=$ poor )

2 U.S. Dept. of Interior, 1984 (BLM condition classification is the same as that used by SCS).

${ }^{3}$ U.S. Dept. of Agriculture, 1977 (USFS condition classification is: $61-100 \%$ climax vegetation $=$ good, $41-60 \%=$ fair, $21-40 \%=$ poor, and $<20 \%=$ very poor $)$.

${ }^{4}$ USFS condition classes reported in 1977 converted to SCS and BLM classification as follows: excellent $=1 / 2$ USFS good, good $=1 / 2 \times$ USFS good $+1 / 2 \times$ USFS fair, fair $=1 / 2 \times$ USFS fair $+1 / 2 \times$ USFS poor, and poor $=1 / 2 \times$ USFS poor + very poor.

Authors are economist, Bureau of Reclamation, Salt Lake City 84147 ; and professor of range economics, Range Science Department, Utah State University, Logan 84322. At the time of the research, Loring was a graduate research assistant, Range Science Department, Utah State University.

Published with the approval of the director, Utah Agricultural Experiment Station as Publication No. 3281.

Manuscript accepted il March 1987. each range condition class by major ownership categories for the state of Utah. While not providing statistical reliability, this table suggests that transfer of Forest Service grazing land to private ownership might, over time, result in a decrease in range condition. Range condition on BLM land also appears to be slightly better than on nonfederal rangeland. The limitations of this general condition information have been well explained in earlier reports (Box et al. 1976, Box 1979). Reliable conclusions cannot be drawn for 2 major reasons: (1) the general survey methods vary between agencies, as do sampling and estimation techniques; and 2) the sampling methodology for assessing range condition varies by agency and sampling year. In view of these limitations, we sampled a single representative county in Utah in order to achieve the statistical reliability needed for comparison of range condition among the different ownership classes.

\section{Study Area}

The area selected for study was Rich County, located in the northeastern part of the Utah panhandle (Fig. 1). Forest Service, BLM, Utah Division of State Lands and Forestry, and the private sector are well represented in the county, and all ownership groups manage grazing on large, contiguous acreages of rangeland. Eleva-

$$
\text { RICH COUNTY }
$$

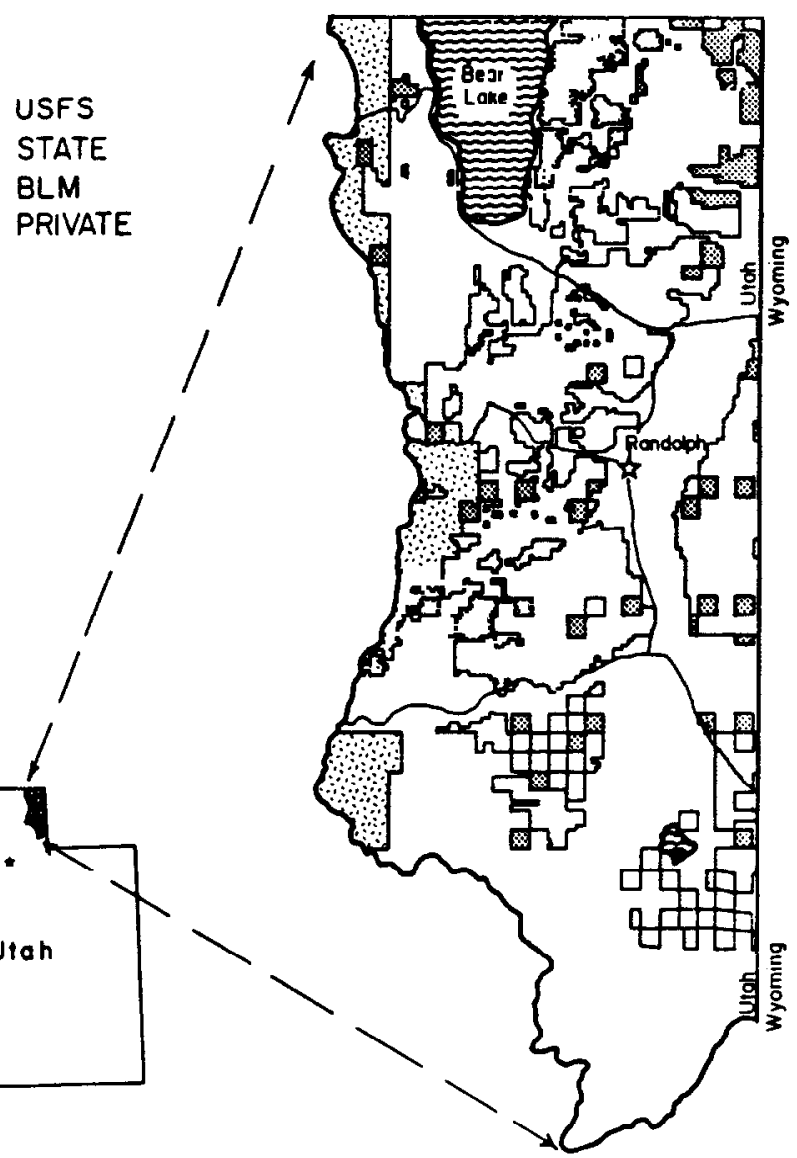

Fig. 1. Map of study area, with regional orientation, showing land ownership. 
tions range from 5,924 feet at Bear Lake to 9,148 feet at Monte Cristo Peak (Soil Conservation Service 1982). Sagebrush-grass communities dominate the 271,614 acres of rangeland (Utah Department of Agriculture 1981). The sagebrush-grass ecosystem provides important spring and fall forage and is critical to the seasonal range use patterns of $\mathrm{Rich}$ County. Seven range sites comprising the majority of acreage within the sagebrush-grass ecosystem were selected for range condition evaluation. In addition to economic importance, these range sites were selected because they readily exhibit vegetation composition responses to livestock use and demonstrate a consistent positive correlation between carrying capacity and range condition rating (Mason 1971). The 7 range sites, as identified by the Soil Conservation Service (1982), are: (1) mountain gravelly loam, (2) mountain stony loam, (3) upland loam, (4) upland shallow loam, (5) upland stony loam, (6) semidesert loam, and (7) semidesert stony loam.

\section{Methods}

The experimental designs were an analysis of variance (ANOVA) randomized block design, using range sites as blocks and ownership classes as treatments, and a paired-plot sampling design applied on range sites that extended across fence ownership boundaries for comparisons between ownership pairs.

All soil mapping units in the county lying within the 7 selected range sites were identified through the use of the SCS soil survey guide (SCS 1982). Areas where grazing was not discretely controlled (i.e., state school sections and areas with checkerboard ownership configurations) were eliminated from the study. The soil mapping units were then numbered separately for each of the 2 experimental designs by range site and by ownership class or pair. Mapping units were selected for field sampling through random generation of their identity numbers. Three soil mapping units for each range site and each ownership class were sampled for the ANOVA test. The paired-plot test required sampling the same soil mapping unit on either side of a fenced ownership boundary. Each combination of range site and ownership pair was presented by 2 mapping units for the paired-plot test. A separate randomization scheme was used for the paired-plots to maintain design independence.

Sampling points were located at the approximate center of each randomly selected range site and the position marked on topographical maps. Range sites dominated by introduced seeded species or small grain cultivation were eliminated and replacement sites were located through the previously described randomized scheme. The number of necessary relocations for each ownership class was recorded.

Field sampling was conducted from early June to early August in 1985. To minimize intra-seasonal variation, sampling began at lower elevations and proceeded to higher elevation sites as the season advanced. Two 100-meter transect lines were extended at right angles from each sampling point and the orientation of the lines was randomly determined. Ten $0.5 \mathrm{~m}^{2}$ circular plots were randomly located along each transect. Green weights for each species at each of the $\mathbf{2 0}$ circular plots were determinated using the double sampling method for weight estimation (Pechanec and Pickford 1937). A subset of 4 randomly selected plots were clipped for regression adjustments of weight estimates. Samples of each plant species at each sampling location were collected for conversion from green to dry-weights.

Range condition rating estimates were based on calculated species composition percentages using the standard SCS method (SCS 1976). Although it is recognized that the concept and measurement of range condition is currently being revised (Range Inventory Standardization Committee 1983), potential natural community indices and updated mapping units were not yet available for Rich County. For this reason, SCS climax composition guides were used to rate range condition.

Some blocks of observations were not available, complicating the statistical analysis of the ANOVA results. For example, the Forest Service boundary did not extend to lower elevation semidesert sites, while the Utah Division of State Lands and Foresty did not control grazing on higher elevation mountain sites (Table 2).

Table 2. Range condition ratings (percent climax vegetation) for $A N O V A$ experimental design.

\begin{tabular}{|c|c|c|c|c|c|}
\hline \multirow{2}{*}{$\begin{array}{l}\text { Range } \\
\text { Site } \\
\text { Number }\end{array}$} & \multirow[b]{2}{*}{ Range Site } & \multicolumn{4}{|c|}{ Soil Mapping Units by Ownership Class } \\
\hline & & State & Private & BLM & USFS \\
\hline 1. & $\begin{array}{l}\text { Mtn. Gravelly } \\
\text { Loam }\end{array}$ & & $\begin{array}{l}28 \\
23 \\
23\end{array}$ & $\begin{array}{l}24 \\
11 \\
29\end{array}$ & $\begin{array}{l}24 \\
22 \\
28\end{array}$ \\
\hline 2. & $\begin{array}{l}\text { Mtn. Stony } \\
\text { Loam }\end{array}$ & & $\begin{array}{l}32 \\
51 \\
38\end{array}$ & $\begin{array}{l}35 \\
34 \\
30\end{array}$ & $\begin{array}{l}44 \\
55 \\
47\end{array}$ \\
\hline 3. & $\begin{array}{l}\text { Upland } \\
\text { Loam }\end{array}$ & $\begin{array}{l}33 \\
60 \\
19\end{array}$ & $\begin{array}{l}41 \\
52 \\
48\end{array}$ & $\begin{array}{l}52 \\
36 \\
40\end{array}$ & \\
\hline 4. & $\begin{array}{c}\text { Upland Shallow } \\
\text { Loam }\end{array}$ & $\begin{array}{l}46 \\
41 \\
40\end{array}$ & $\begin{array}{l}47 \\
40 \\
40\end{array}$ & $\begin{array}{l}36 \\
35 \\
39\end{array}$ & $\begin{array}{l}34 \\
43 \\
48\end{array}$ \\
\hline 5. & $\begin{array}{l}\text { Upland Stony } \\
\text { Loam }\end{array}$ & $\begin{array}{l}26 \\
34 \\
29\end{array}$ & $\begin{array}{l}34 \\
29 \\
26\end{array}$ & $\begin{array}{l}17 \\
31 \\
44\end{array}$ & $\begin{array}{l}33 \\
35 \\
28\end{array}$ \\
\hline 6. & $\begin{array}{l}\text { Semi-desert } \\
\text { Loam }\end{array}$ & $\begin{array}{l}46 \\
55 \\
55\end{array}$ & $\begin{array}{l}53 \\
60 \\
41\end{array}$ & $\begin{array}{l}49 \\
53 \\
46\end{array}$ & \\
\hline 7. & $\begin{array}{l}\text { Semi-desert } \\
\text { Stony Loam }\end{array}$ & $\begin{array}{l}36 \\
23 \\
43\end{array}$ & $\begin{array}{l}63 \\
51 \\
38\end{array}$ & $\begin{array}{l}47 \\
47 \\
38\end{array}$ & \\
\hline
\end{tabular}

For this reason, analyses of the 2 main effects of ownership class and range site, as well as the analysis of the interaction effect, were based on 3 data subsets from the principal design (Table 3). Average range condition ratings for the ownership classes for each data subset were then compared using Least Significant Difference (LSD) confidence intervals $(p<10)$ based on the difference between 2 means (Neter and Wasserman 1974).

Table 3. F-test results for data subsets of the ANOVA design.

\begin{tabular}{|c|c|c|c|c|c|}
\hline Subset & $\begin{array}{c}\text { Number } \\
\text { of } \\
\text { Range } \\
\text { Sites }\end{array}$ & Comparison & Source & F ratio & $\begin{array}{c}\text { P Level } \\
\text { of } \\
\text { Signifi- } \\
\text { cance }\end{array}$ \\
\hline A & 4 & $\begin{array}{l}\text { Priv. vs BLM } \\
\text { vs USFS }\end{array}$ & $\begin{array}{c}\text { Ownership (0) } \\
\text { Range Site (R) } \\
0 \times \mathbf{R}\end{array}$ & $\begin{array}{r}2.64 \\
11.09 \\
0.83\end{array}$ & $\begin{array}{l}0.09 \\
0.00 \\
0.56\end{array}$ \\
\hline B & 7 & Priv. vs. BLM & $\begin{array}{c}\text { Ownership (0) } \\
\text { Range Site (R) } \\
0 \times \mathbf{R}\end{array}$ & $\begin{array}{l}3.46 \\
8.38 \\
0.22\end{array}$ & $\begin{array}{l}0.07 \\
0.00 \\
0.97\end{array}$ \\
\hline $\mathrm{C}$ & 5 & $\begin{array}{l}\text { St. vs Priv. vs } \\
\text { BLM }\end{array}$ & $\begin{array}{c}\text { Ownership (0) } \\
\text { Range site (R) } \\
0 \times \mathbf{R}\end{array}$ & $\begin{array}{l}1.30 \\
6.31 \\
0.68\end{array}$ & $\begin{array}{l}0.29 \\
0.00 \\
0.71\end{array}$ \\
\hline
\end{tabular}

The paired t-test (significance set at $p<.10$ ) was used in the statistical analysis for the paired-plot design. It was not possible to directly compare Forest Service and state-owned lands because there were no adjacent tracts owned by these 2 agencies in Rich County.

\section{Results}

Range condition ratings for the ANOVA design are presented in Table 2. The 3 data subsets used for statistical analysis are as follows: Subset A (range sites 1, 2, 4, and 5) was used to compare 
private, BLM, and Forest Service land; Subset B (all 7 range sites) was used to compare private and BLM land; Subset C (range sites 3 through 7) was used to compare state, private, and BLM land.

Although range condition ratings were significantly influenced by range site blocks (Table 3), pair-wise comparisons of block means revealed no recognizable trends. Significant mean differences within an elevational grouping (i.e., mountain, upland, and semidesert) occurred as often as significant differences among elevation groups. Pair-wise comparisons also showed no apparent effect due to loamy, shallow, or stony soil characteristics. Inconsistencies in the percentages of plant species counted toward climax in the SCS technical guides may have contributed to this unclear effect. However, further analysis was not pursued because there was no significant interaction between range site and ownership (Table 3).

Data subsets A and B demonstrated a significant $(p<.10)$ relationship between ownership class and range condition (Table 3 ). Further analysis of these subsets using pair-wise comparison (Table 4) showed that Forest Service range condition ratings were significantly higher $(p<10)$ than those for BLM land (Subset A). When all 7 range sites were examined (Subset B), private rangeland was also in higher condition than BLM land. Though not statistically significant, private land also tended to be in higher condition than state land.

Table 4. Results of LSD pair-wise comparison of mean difference for data subsets of the ANOVA design.

\begin{tabular}{|c|c|c|c|c|c|}
\hline Subset & $\begin{array}{c}\text { Number } \\
\text { of } \\
\text { Range } \\
\text { Sites }\end{array}$ & Comparison & $\begin{array}{l}\text { Owner- } \\
\text { ship }\end{array}$ & Mean & $\begin{array}{c}\text { Pair } \\
\text { Comparison }\end{array}$ \\
\hline $\mathbf{A}$ & 4 & $\begin{array}{l}\text { Priv. vs BLM } \\
\text { vs USFS }\end{array}$ & $\begin{array}{l}\text { Priv. } \\
\text { BLM } \\
\text { USFS }\end{array}$ & $\begin{array}{l}35.08 \\
30.42 \\
36.75\end{array}$ & $\begin{array}{l}\text { Priv. vs BLM } \\
\text { Priv. vs USFS } \\
\text { BLM vs USFS }\end{array}$ \\
\hline B & 7 & Priv, vs BLM & $\begin{array}{l}\text { Priv. } \\
\text { BLM }\end{array}$ & $\begin{array}{l}41.33 \\
36.81\end{array}$ & Priv. vs BLM* \\
\hline C & 5 & $\begin{array}{l}\text { St. vs Priv. vs } \\
\text { BLM }\end{array}$ & $\begin{array}{l}\text { State } \\
\text { Priv. } \\
\text { BLM }\end{array}$ & $\begin{array}{l}39.07 \\
44.20 \\
40.67\end{array}$ & $\begin{array}{l}\text { St. vs Priv. } \\
\text { St. vs BLM } \\
\text { Priv. vs. BLM }\end{array}$ \\
\hline
\end{tabular}

*Significant at $p<$. 10

Paired t-test comparisons showed a stronger relationship between range condition and ownership class than did the ANOVA tests (Table 5). Forest Service rangeland was in higher $(p<10)$ range condition than either private or BLM lands. However, there was no significant difference between the condition of BLM and private rangeland in the paired-plot experiment. Range condition on private land was significantly higher than on state-owned range-

Table 5. Summary of results for the paired-plot design.

\begin{tabular}{|c|c|c|c|c|c|}
\hline Pair & Ownership & Mean & $\begin{array}{l}\text { Sample } \\
\text { Size }\end{array}$ & $\mathrm{t}$ & $\begin{array}{l}\text { P level of } \\
\text { Significance }\end{array}$ \\
\hline Priv. vs. USFS & $\begin{array}{l}\text { Priv. } \\
\text { USFS }\end{array}$ & $\begin{array}{l}29.38 \\
34.88\end{array}$ & 8 & 1.91 & 0.10 \\
\hline Priv. vs BLM & $\begin{array}{l}\text { Priv. } \\
\text { BLM }\end{array}$ & $\begin{array}{l}37.60 \\
38.60\end{array}$ & 10 & 0.21 & 0.84 \\
\hline USFS vs BLM & $\begin{array}{l}\text { USFS } \\
\text { BLM }\end{array}$ & $\begin{array}{l}39.50 \\
38.20\end{array}$ & 8 & 3.87 & 0.01 \\
\hline Priv. vs St. & $\begin{array}{l}\text { Priv. } \\
\text { St. }\end{array}$ & $\begin{array}{l}42.50 \\
35.60\end{array}$ & 10 & 1.87 & 0.09 \\
\hline BLM vs St. & $\begin{array}{c}\text { BLM } \\
\text { St. }\end{array}$ & $\begin{array}{l}50.33 \\
34.67\end{array}$ & 3 & 1.84 & 0.21 \\
\hline
\end{tabular}

land, a result consistent with the results of the ANOVA pair-wise comparison. Although there was a large apparent difference between average condition of BLM and state rangeland, it was not statistically significant, due in part to an unavoidably small sample size.

Different sampling strategies of the 2 experimental designs explains why a stronger relationship between ownership and range condition was demonstrated by the paired-plot analysis than by the ANOVA. The minor differences in slope, aspect, and soil character change soil mapping unit delineations but do not affect SCS delineation of range sites. Samples in paired-plot comparisons involved the same soil mapping unit for each ownership pair, effectively removing all sources of variation other than ownership class. Thus, the paired-plot design is more accurate in detecting differences between ownership groups. No contradictory outcomes were generated by the 2 experimental designs.

\section{Discussion and Conclusions}

\section{Land Transfer Implications}

The relationship between ownership class and range condition in Rich County corresponded closely with the information for Utah in Table 1. Forest Service rangeland was in higher condition than either BLM or private land. Thus, any transfer of Rich County Forest Service grazing land to private ownership might bring a decline in range condition. The higher condition of Forest Service rangeland compared to BLM land may reflect the historical fact that the Forest Service acquired control of livestock grazing several decades before the BLM (Wagner 1978). It is more difficult to predict the effects of privatization of BLM rangeland for several reasons. First, even though results of the ANOVA indicated that private rangeland was in higher range condition than BLM land, this conclusion was not supported by the more conservative paired $t$-test analysis.

Second, the statistical analysis did not consider how historical regulation of grazing has affected present condition of BLM rangeland. As was noted in Senate Document No. 199 (U.S. Senate 1936), the most severe ecological degradation prior to the 1934 Taylor Grazing Act occurred on public domain rangeland that BLM later acquired. Thus, the fact that range condition of Rich County BLM lands is currently comparable to that of private rangelands might or might not be a valid argument against proposed privatization of BLM lands.

Finally, BLM and private range managers have different management objectives. Twenty-nine percent of the sample sites randomly located on private rangeland had to be relocated due to seedings of crested wheatgrass (Agropyron cristatum (L.) Gaertn.) monocultures, while only $1 \%$ of BLM sites were relocated for this reason. Therefore, transfer of Rich County BLM land to private ownership might bring increased seedings of non-native monocultures, an ecological change that should be considered.

\section{The Effect of Property Rights}

Comparisons of range condition on federal and private lands in Rich County were different than expected, based on incentive theory of renewable resource use. Resource economists contend that efficient user incentives occur only when all benefits and costs of using the resource accrue solely to the user (Tietenberg 1984). Although it is argued that this exclusivity requirement is not met by federal land grazing permits, other factors affecting range condition may be more important than nonexclusivity. Change in range condition is a subtle and continuous process involving complex changes in the composition of plant communities. Sensitivity to these changes, which depends on available budget and expertise, can greatly affect range condition. The confounding influences of management objectives, expertise, budgetary allocation, and enforcement capability may have overshadowed the effect of ill-defined federal property rights. Consequently, any proposal for federal land privatization based solely on the expected influence of property rights on user incentives seriously oversimplifies the situation. 
Table 6. Comparison of agency expenditures on grazing programs in Utah for 1984.

\begin{tabular}{lccl}
\hline \hline Agency & $\begin{array}{c}\text { 1984 Expenditures } \\
\text { for Grazing Program(\$) Managed }\end{array}$ & $\begin{array}{c}\text { Total Acres' } \\
\text { \$/ac. }\end{array}$ \\
\hline USFS & $2,198,800^{2}$ & $7,990,710^{3}$ & 0.275 \\
BLM & $3,331,969$ & $22,708,363$ & 0.146 \\
State of & 228,000 & $3,785,296$ & 0.076 \\
Utah & 306,000 & & 0.081 \\
\hline
\end{tabular}

'Total acreages are used for consistency

2U.S. Dept. of Agriculture, 1984b

UU.S. Dept. of Agriculture, 1985

4 RI.M, 1982 and 1985

sUtah Auditor General 1986 report to the Utah legislature on grazing program income for fiscal 1984. (Includes high and low estimates).

Even though property rights had less effect than other factors, this does not imply that property rights are not important. The comparison of private rangeland and Utah Division of State Lands and Forestry rangeland illustrates how property rights affect range condition. The goal of the State Lands and Forestry Division is to allocate the use of state lands to activities promising the highest returns to the state. Programs supervised by the State Lands and Forestry Division are accountable to the Utah Legislature Auditor General's Office (Utah Auditor General report to Utah legislature 1985). Consequently, the range conservation objective is often secondary to that of generating income. Twenty-seven percent of the randomly selected sample sites on state-owned rangeland had to be relocated because they were in dryland wheat production, with some cultivation observed on soil mapping units with slopes averaging about $20 \%$ (SCS 1982).

The income-generating goals of the State Lands and Forestry Division may create strong incentives to not invest budget and labor in long-term improvements of range condition. Table 6 compares grazing program expenditures for the Forest Service, BLM and State of Utah. Relative per acre expenditures of the agencies follow the same pattern as the range condition ratings discussed above. The apparent correlation between grazing program expenditures and range condition among the agencies indicates that the level of management effort may be more important than the effects of public land property rights.

Range condition comparisons between Rich County private and state lands conformed more closely to expectations based on property rights incentive theory. Because per acre grazing management expenditures were small on state lands (compared to federal lands), state management effort had less confounding influence on the relationship between public land property rights and range condition.

\section{Literature Cited}

Baden, J., and R. Stroup. 1977. Property rights, environmental quality and the management of national forests, p. 229-240. In: Garrett Hardin and John Baden (eds), Managing the Commons. W.H. Freeman and Company, San Francisco, Calif.

Box, T.W. 1979. The American rangelands: Their condition and policy implications for management, p. 18-27. In: Rangeland Policies for the Future. U.S. Dep. Agr. Policy Symposium Proceedings. Tucson, Ariz.

Box, T.W., D.D. Dwyer, and F.H. Wagner. 1976. The public range and its management. Report to the President's Council on Environmental Quality. March 19, 1976.

Bureau of Land Management. 1982. BLM facts and figures for Utah, 1982. Utah State Office. Salt Lake City, Utah.

Bureau of I and Management. 1985. BLM facts and figures for Utah, 1985. Utah State Office. Salt Lake City, Utah.

Hardin, G. 1977. An operational analysis of responsibility, p. 66-75. In: Garrett Hardin and John Baden (eds), Managing the Commons. W.H. Freeman and Company, San Francisco, Calif.

Mason, Lamar R. 1971. Yield and composition of Utah's range sites. Soil Conservation Service, USDA. Salt Lake City, Utah.

Neter, John, and William Wasserman. 1974. Applied linear statistical models. Richard D. Irwin, Inc., Homewood, Ill.

Pechanec, J.F. and G.D. Pickford. 1937. A weight estimate method for determination of range or pasture production. J. Amer. Soc. Agron. 29:894-904.

Range Inventory Standardization Committee. 1983. Guidelines and terminology for range inventories and monitoring. Society for Range Management, Denver, Colo.

Rosetta, Noel. 1985. Herds, herds on the Range. The Sierra Club Bulletin 70:43-47.

Soil Conservation Service. 1976. National range handbook. USDA. U.S. Gov. Printing Office. Washington, D.C.

Soll Conservation Service. 1982. Soil survey of Rich County, Utah. USDA. U.S. Gov. Printing Office, Washington, D.C.

Tietenberg, Tom. 1984. Environmental and natural resource economics. Scott, Foresman and Company, Glenview, Illi.

U.S. Department of Agriculture. 1977. Region 4 summary of range condition by states. Ogden, Utah.

U.S. Department of Agriculture. 1984a. Basic statistics, 1982. National Resources Inventory. SCS and Iowa State Univ. U.S. Gov. Printing Office, Washington, D.C.

U.S. Department of Agriculture. 1984b. Forest Service fiscal year financial summary data, Region 4. Ogden, Utah.

U.S. Department of Agriculture. 1985. Land areas of the national forest system as of September 30, 1985. FS-383. U.S. Govt. Printing Office, Washington, D.C.

U.S. Department of Interior. 1984. 50 years of public land management. U.S. Gov. Printing Office, Washington, D.C.

U.S. Sennte. 1936. The Western Range. U.S. Senate Document 199, 74th Congress, 2nd Session.

Utah State Department of Agriculture. 1981. Utah Agricultural Statistics. Salt Lake City, Utah.

Wagner, Frederick H. 1978. Livestock grazing and the livestock industry, p. 121-145 In: Howard P. Brodaw (ed), Wildlife in America. Council on Environmental Quality. U.S. Gov. Printing Office, Washington, D.C.

Workman, John P., E. Bruce Godfrey, Allen D. LeBaron, and Darwin B. Nielsen. 1981. Net economic costs of the proposed transfer of Utah's federal lands to state ownership. Rangelands. 3:6-7. 